Electrochemical Cell Design 


\section{Electrochemical Cell Design}

Edited by

Ralph E. White

Department of Chemical Engineering

Texas A\&M University

College Station, Texas 
Library of Congress Cataloging in Publication Data

Main entry under title:

Electrochemical cell design.

"Selected contributions from a symposium on recent advances in electrochemical cell design, held March 27-31, 1983, in Houston, Texas"-T.p. verso.

Bibliography: $p$.

Includes index.

1. Electrolytic cells-Congresses. 2. Electric batteries-Congresses. I. White, Ralph E.

QD568.E44 1984

$621.31 / 242$

84-11710

ISBN-13: 978-1-4612-9723-9

e-ISBN-13: 978-1-4613-2795-0

DOI: 10.1007/978-1-4613-2795-0

Selected contributions from a symposium on Recent Advances in

Electrochemical Cell Design, held March 27-31, 1983, in Houston, Texas

(C) 1984 Plenum Press, New York

Softcover reprint of the hardcover 1st edition 1984

A Division of Plenum Publishing Corporation

233 Spring Street, New York, N.Y. 10013

All rights reserved

No part of this book may be reproduced, stored in a retrieval system, or transmitted in any form or by any means, electronic, mechanical, photocopying, microfilming, recording, or otherwise, without written permission from the Publisher 
PREFACE

This book consists essentially of a collection of papers that were contributed to a national meeting held in Houston, Texas, in 1983. The papers contained herein cover a wide range of electrochemical engineering topics and should serve as useful starting points in the design of electrochemical cells.

The editor would like to thank the authors for their contributions and patience and the typists, Mrs. Susan Firth and Mrs. Jeri. Saulsbury, for their efforts. Also, the editor would like to thank Mr. T. Nguyen and Ms. M. A. Nictrolson for their he1p in preparing the index of this book.

R.E. White 
CONTENTS

Design and Development of Electrochemical

Chlor-Alkali Cells ............... 1

S. N. Chatterjee

A Simple Model of a Diaphragm - Type Chlorine Cel1 . . . .

R. E. White, J. S. Beckerdite, and J. Van Zee

Design Principles for Chlorine Membrane Cells . . . . . . 61

K. H. Simmrock

Hydroxyl Ion Migration, Chemical Reactions, Water Transport and Other Effects as Optimizing Parameters in Cross-, Co- and Countercurrently Operated Membrane Cells for the Chlor/Alkali Electrolysis . . . . . . . . .

K. H. Simmrock

Hydraulic Modelling as an Aid to Electrochemical Cell Design - 115

I. Wardle

Calculating Mechanical Component Voltage Drops in Electrochemical Cells ............ 123

I. Wardle

Electrolysis Cell Design for Ion Exchange Membrane

Chlor-Alkali Process . . . . . . . . . . 135

M. Seko, A. Yomiyama, and S. Ogawa

Experiences with a Bench-Scale Electrochemical Plant. . . . 161

R. D. Goodin, R. E. W. Jansson, and R. J. Marshall

Economic Driving Force in Electro-Organic Synthesis . . . 175

R. E. W. Jansson

Design of SU Modularized Electrochemical Cells . . . . . . 197

A. Bjarek1int, L. Carlsson, and B. Sandegren 
Electrochemical Techniques for the Extraction of Heavy Metals

in Industry: Concepts, Apparatus and Cost . . . . 207

W. Samhaber

The Design and Application of Rotating Cylinder Electrode

Technology to Continuous Production of Metal . . . . 225

N. A. Gardner and F. C. Walsh

Shunt Current Control in Electrochemical Systems -

Theoretical Analysis . . . . . . . . . . 259

P. G. Grimes, R. J. Bellows, and M. Zahn

Shunt Current Control Methods in Electrochemical

Systems - Applications . . . . . . . . . . 277

P. G. Grimes and R. J. Bellows

A Simple Mode1 of Exxon's $\mathrm{Zn} / \mathrm{Br}_{2}$ Battery . . . . . . . . 293

J. Van Zee, R. E. White, P. G. Grimes, and R. J. Bellows

A Finite Element Model of Bipolar Plate Cells . . . . . . 311

J. W. Holmes and R. E. White

Changes in Overall Ohmic Resistance Due to

Migration/Diffusion of Electrolytes . . . . . . . 337

K. H. Lim and E. I. Frances

Mathematical Model for Design of Battery

Electrodes: Lead-Acid Cell Modelling . . . . . 357

W. G. Sunu

Extension of Newman's Numerical Technique to

Pentadiagonal Systems of Equations . . . . . . . . 377

J. Van Zee, G. Kleine, R. E. White, and J. Newman

Index . . . . . . . . . . . . . . . . 391 